\title{
Museums, Memory and History
}

Graham Black, Reader in Public History \& Heritage Management, Nottingham Trent

University, graham.black@ntu.ac.uk

Key words: cultural memory, museums, multiple perspectives, audiences. Introduction

This article seeks to explore the complex relationship between history museums, memory, history and audiences. I have focused on museum practice, rather than the theoretical discussions of, for example, Benjamin, Foucault or Nora, because it is through practice that history and memory in the museum is constructed mediated, communicated and responded to.

Museums have a commitment not only to collect, conserve and document material evidence of the past but also to make it publicly accessible. In selecting what to collect, they define what is or is not history. In preserving their collections in perpetuity they act as a permanent memory store. In the way they display and interpret that material evidence, they construct and transmit meanings. In contemporary museum display, there is an on-going conflict between the construction of meanings that support an authorised collective memory, frequently linked to a linear narrative of progress, and an ambition to act as places of pluralism and inclusion that 'give voice to the disenfranchised, the oppressed and the silenced'. ${ }^{1}$ Furthermore, visitors to museums are not passive recipients. Rather, in the process of engaging with the collections and associated interpretive material on display, visitors add new content to their existing knowledge and understanding, and construct their own meanings. Increasing digital access to museum collections and documentation has added further to the democratization of meaning-making. ${ }^{2}$ History is thus selected, constructed and transmitted by museums and then, in the process of being experienced by visitors, it is transformed into 'something else - 
their own understanding of the past, a type of "historical sense" independent of the professional historian's ideal...,3

\section{Museum collections and constructing the past}

In Pasts Beyond Memory (2004), Bennett discusses the rise and impact of the 'evolutionary museum' which grew out of major advances in the historical sciences geology, palaeontology, natural history, prehistoric archaeology and anthropology particularly in the mid- to late-nineteenth-century. The techniques used by the historical sciences, including stratification, rock formation and typologies, severed the connection that restricted the past to the written record and oral tradition. The silent voices of prehistory could be heard for the first time:

Limitless vistas of pasts going back beyond human existence, let alone memory, came rapidly into view as the once mute traces they had left behind were made eloquent through the application of new methods of analysis and interpretation. ${ }^{4}$ It was museum exhibition, based on evolutionary principles of classification, which made prehistory visible. Here, museums were incubators of new understanding, developing the rules for classification and typologies. From the same evolutionary model came the concept of the body as a palimpsest retaining traces of past human development, a 'memory machine' in its own right 'visualised archaeologically as so many strata superimposed one on top of the other' 5

This role of the museum as both incubator and transmitter of knowledge and understanding was not a new development of the nineteenth century. In her book, Wondrous Curiosities, Moser explores approaches to museum display from early cabinets of curiosity in the sixteenth century to what can be described as the 'making' of Ancient Egypt, as the public understands it, through re-displays of the British Museum's Egyptian collections from the mid eighteenth to the later nineteenth 
centuries. From the outset, she traces a triple function for what became the public museum -

- studying collections to develop knowledge and understanding;

- recognising that, through defined display practices, these collections could be endowed with the power to transmit this knowledge to a wider audience; and

- coming to understand that those same display practices enabled the collector/scientist/curator to construct/create the very knowledge that was being transmitted - expressing ideas and concepts not only through layout/visual effect, but incorporating labels and guided tours.

Thus, the 'geological archaeologists' such as Pitt Rivers were maintaining an established curatorial tradition as they sought to classify and interpret the emerging prehistoric artefactual evidence, chiefly through the development and sequencing of typologies based on both newly uncovered material and the reassembling of existing collections. But this classificatory, typological approach to studying the past had severe limitations, ones that can still be witnessed in many archaeological exhibits today. Viewed and displayed purely as abstract evidence - objects as objective accounts of the past - these collections give a very limited insight into the past, devoid of the memory of the people who made and used them and existing only in an artificially created archaeological time frame.

The alternatives to this approach involved and involve:

\section{Seeking contemporary parallels to past societies for comparison}

At the time of the development of evolutionary museums, prehistoric archaeology and anthropology were seen as distinguishable mainly, as Bennett puts it, 'in terms of their spatial distribution': "... the one was applied 'over here' to the 
prehistory of Europe, the other 'over there' to the interpretation of the prehistoric 'past within the present' represented by colonised peoples."

Thus distant peoples were viewed as living memories of the long-distant past, 'static and without history' ${ }^{7}$, somewhere near the bottom layers of the archaeological strata that made up modern man. As such, races could be ranked hierarchically depending on the degree of historical depth they were accorded, and an assessment of their capacity for evolutionary self-development. In this context, Western middle and upper class males came top, with Australian aboriginals bottom. Thus museums, in playing a pivotal role in establishing the concept of prehistory and in using the Darwinian model to develop classification systems and typologies to effectively segment time and plot change over time, also developed and exhibited the concept of the progressive Western male and the static 'Other' who could be studied to give westerners direct access to the likely lives of their prehistoric predecessors.

Re-experiencing objects as the touchable memory of past societies

There is a long-established association of memory with preservation and storage. It is in this sense that the museum can be seen as much more than a typological collection of evidence of past time frames but, rather, as the storehouse and protector of the memory of humankind, through the objects held, documented and cared for in its collections. Objects - and I use this term in the broadest sense are the 'only class of historical events that occurred in the past but survive into the present. They can be re-experienced; they are authentic, primary historical material... ${ }^{8}$ Such objects represent the visible and touchable outer world of the memory of past societies - a cultural memory that can last thousands of years but is also relevant to recent times. As first-hand memory disappears, the objects made and used even in the recent past shape our views. Thus museums become places 
where culture, history and memory meet. But they meet in a form mediated through the process of selection, collection, preservation and display.

Museum definitions of culture seek to take account of the full range of human experience and activity, incorporating much that is 'handed down, learned, taught, researched, interpreted and practiced. ${ }^{9}$ Its outward manifestations will include both social practices and physical evidence, but it is specific types of 'material culture' particularly inorganic physical remains including buildings and many smaller objects - that most readily survive to reflect past cultures and that continue to represent core elements of modern society. Until recent decades, it was largely these types of material culture that museums collected, preserved and stored, rather than 'culture' itself.

As Crane points out, in collecting these objects, museums not only store cultural memory, they are also directly involved in creating and manipulating it: "Preservation in the museum fixes the memory of entire cultures through representative objects by selecting what 'deserves' to be kept, remembered, treasured..."10

Through exhibitions, programming and other means of transmission, museums actively define and represent cultural memory:

... being displayed means being incorporated into the extra-institutional memory of the museum visitors ... a notion of memory objectified, not belonging to any one individual so much as to audiences, publics, collectives, and nations, and represented via the museum collections. ${ }^{11}$

In this sense, you could say that the study of cultural memory moves away from the historian's concern with the past to a contemporary exploration of how the past is represented, or not represented, and transmitted in the present. As such, objects serve cultural memory in a number of ways: 
a) Objects that are created for their memory role, or have that role foisted upon them

These include: those directly associated with rites and ceremonies and customs, themselves linked to memory; those produced directly as commemoratives (of individuals or events) or souvenirs (of places); and those collected or retained, by individuals or communities, for the memories they are associated with, from family heirlooms to the darkest of events. In terms of commemoratives, for example, Kwint notes that approximately a tenth of the decorative goods that first began to appear in English plebeian households during the seventeenth century consisted of commemorative plates, mugs and jugs marking national and family events from the Civil War onwards. ${ }^{12}$ In contemporary society, the house key has become one of the most poignant of objects the world over, symbolic of the refugee's desire to return home.

\section{b) Objects that trigger remembering}

When people use museums, they bring their life experiences with them.

Often, their encounter with objects in the museum brings back vivid recollections, half-remembered places and emotions which would otherwise have remained forgotten. It is a commonplace for such memories to be discussed amongst the social or family group taking part in the visit. From the exhibits encountered, and the memories evoked and shared, new meanings are made. In discussing the triggering of such memories, Kavanagh speaks of the museum as a 'dream space':

... many things might tumble through our minds: bits of songs, half-written shopping lists, things left unsaid. The shape or shadow of something, its texture or colour, the operation of space and people moving through it can be triggers to an endless range 
of personal associations... We have to accept more fully the imagination, emotions, senses and memories as vital components of the experience of museums. ${ }^{13}$

These memories and meanings arise not as a result of only visual access to museum collections but also from other forms of access. The importance of smell in provoking memory has long been understood. Recent research reflects the increasing understanding of the complexity of the tactile memory system we operate under and the impact that touching objects can have on bringing memories to mind. ${ }^{14}$ The opportunity to handle, explore and experience objects has also become part of good practice in reminiscence work, relating to aspects of remembered lifeexperience. ${ }^{15}$ From experiences on museum visits, to organised group reminiscence sessions, there is substantial and growing evidence of museum objects as triggers of individual memories.

\section{c) Objects that reflect the society and culture that produced them}

A core objective in the study of historical objects, or 'material culture', is to better understand the societies/cultures within which they were made and used. ${ }^{16}$ Such objects evoke a sense of time, place and society beyond individual memory and can play a powerful role in defining a community's memories of its collective past, its social practices, its attitudes and beliefs, etc. In terms of defining and transmitting cultural memory, the issue is not what memories these objects hold but rather which memories/meanings are selected for transmission and how the selection process works. The central criticism of museums in this regard is that this process is geared to presenting a single, authoritative view of the past - that of the elite. I will return to this later, in discussing collective memory. 
d) Objects that retain evidence of the craft traditions that produced them

I am referring here to the retention of cultural memory across generations through the continuation of cultural and craft practice - the passing on of traditional skills and techniques, acquired in turn by each new practitioner through watching craftsmen, practising under their guidance and studying examples of their craft. ${ }^{17}$ In the case of the latter, the object memory lives on after the maker and user and becomes a vital link to the craft in its own right. Today many of these objects are held in museums, a reflection of the value society places on the established usages of our communities. But museums are also proactive in retaining and promoting craft skills

The role of the museum as the memory of humankind can be particularly important for societies that could be described as 'intangible cultures' (because they are non-literate and where almost all the material forms of cultural expression are made from organic biological materials that disappear in time, particularly in tropical climates). For example Pacific museums, through their regional organisation, the Pacific Islands Museums Association, include amongst their key functions the protection and promotion of traditional art forms and cultures and preserving the region's material culture. ${ }^{18}$

But museums do not only seek to preserve tradition. They also, through their collections, establish when and how that tradition is overturned. The material culture of the prehistoric and early historic world is characterised by long-lasting styles.

Since then we have seen both an increasing speed of change and rapidly growing volumes in which material culture is present. Assman suggests that the key moment of change occurred with the invention of writing when he believes the prioritisation of tradition was replaced by a measure of what could be added that was new and individual. ${ }^{19}$ Crowley in his The Invention of Comfort links major developments in 
material culture in Western society to changing ideas of physical well-being in the post-Reformation world. ${ }^{20}$

\section{e) Museum collections as self-conscious memory}

Edge and Weiner point to critics of the first museums, such as Hegel and Quatremere de Quincy, who 'complained that instead of preserving history, the museum would destroy it' by taking objects out of their daily existence and out of context, thereby removing their authenticity and institutionalizing them. 'Placed in the foreign context of the museum, the objects are meaningless caricatures. The museum then attests to the failure of the present to construct a reasonable relationship with the past.' 21

The critics have not gone away. Such concerns are reflected, for example, in the writings of Adorno ${ }^{22}$, and particularly in Nora's work ${ }^{23}$ where he seeks to make a distinction between self-consciously created places of memory and authentic 'environments of memory', describing museums, memorials and archives as 'prosthetic artefacts to replace natural connections to reality'. ${ }^{24}$ Like Bennett ${ }^{25} \mathrm{I}$ am sceptical of Nora's authentic lieux de memoires and doubt that collective memory was ever spontaneous. However, the comparatively recent rise of the ecomuseum, embedded in and part of its community, is one response by the history museum profession to this criticism of removal from context. ${ }^{26}$ Often such museums also promote consciousness-raising within communities, engaging people with past traditions. We can see this also, for example, in the rise of Native American tribal museums in the USA. But even here, the construction of cultural memory continues apace. A conservative focus on religion, ceremony and tradition at the National Museum of the American Indian, since its founding in 1989, has downplayed other aspects of culture. ${ }^{27}$ 
However, one specific type of museum stands out as an authentic site of memory, namely those museums which occupy sites which exemplify man's inhumanity to man. In 1999 a number of these museums came together to found the International Coalition of Sites of Conscience, currently with seventeen members worldwide (www.sitesofconscience.org). These museums are "dedicated to remembering past struggles and addressing their contemporary legacies"28, including state terror, slavery and poverty. Members include the Terezin Memorial in the Czech Republic, the District Six Museum in South Africa, the Gulag Museum at Perm-36 in Russia, the Memoria Abierta in Argentina, the National Civil Rights Museum in the USA, the Maison des Esclaves in Senegal and the Southwell Workhouse in the UK. Here are museums where painful memory of the past is integral to content, yet they are also morally committed to tackling these issues today. For them "memory is a critical language and terrain of human rights." 29 Through preserving these sites, evidence of past human rights violations can be maintained, communicated and debated, and tactics developed and refined that may prevent the violations happening again.

\section{From 'official past' to multiple perspectives}

The rise of the political nation placed the history profession seemingly in control of official memory for most of the nineteenth and twentieth centuries, tasked with re-creating and promoting a unified past that underpinned national identity. However, the official memory of a given society has never existed solely in the written work of historians. It has also been constructed through what we now refer to as the collective memory of the group. If the history of a group is about its past, collective memory is about the continual presence of that past in the present. ${ }^{30}$ As such, it is maintained through rituals, ceremonies, 'traditions', commemorations, 
festivals, sites, memorials and institutions (including museums) created and preserved to reinforce it. Thus museums anchored and communicated official memory by giving it physical form through the material they collected, preserved and displayed. ${ }^{31}$

The process by which communities and nations remember collectively itself has a history. ${ }^{32}$ For museums, as for the official memory written by historians, selectivity has been a key element. The core criticism of museums as instruments of the state is that the version of the past they have given form to is based on the selective collection, preservation and presentation of evidence of past human society which prioritises an elite. Objects relating to wealthier classes have a far higher likelihood of survival. The retention of such objects by museums is also likely to be the result of past collecting policies, reflecting the priorities and tastes of the ruling bodies within a community. As previously noted, in the process of collecting this material, museums both create knowledge and manipulate it, and through interpretation and transmission they define its relative importance or authority. Meanwhile, through the silences in a museum's collections and narratives, 'in what it allows to go unnoticed, unrecognized and unacknowledged'33, the contribution of the bulk of the community the museum serves is ignored. Museums in the past were thus seen to legitimate a particular construct, an 'official' past, focused on the activities of the elite, and make this part of the collective memory of society. As such, Davison suggests such museums could be described more accurately as places of selective memory rather than collective memory. ${ }^{34}$

Because of the way objects have been collected in the past, presenting history in a museum is also partly about the history of the museum itself. Thus we can note that the beginnings of change in the way museums sought to collect and present the past took flight at the same time as the rise of the 'new social history' in 
the 1960s, although there is some relevant earlier work. The new social and industrial history museums which grew up opened the gates to pluralism and multiple perspectives, based on the principle that the present is the result of the life contributions of all who have made up society in the past, not just of the elites. The development of these new museum fields led in turn to a surge in the collection of the 'everyday', particularly in the 1960 s and 1970s. Kavanagh points to the limited attention that has been paid to the process by which these new collections were formed. ${ }^{35}$ But this period also saw a critique of the primacy of the object, reflecting both the lack of representativeness in most museum collections, and a growth of curatorial understanding of the importance of other sources of evidence when seeking to reflect previously silent voices. ${ }^{36}$ Thus, alongside the development of new social and industrial history object collections came an extension of the museum remit to include archives, photographs, film and, particularly, oral histories, representing both individual and community memories, and seen as a direct connection between a 'lived' past and the present. Through this material, a new window was opened into the life experiences and contributions of working men and women.

Kavanagh charts the different forms of oral testimony that attracted UK museums, beginning with the recording of oral traditions in 1957 by what is now the Museum of Welsh Life at St Fagan's, with advice from the School of Scottish Studies and the Irish Folk Lore Commission. In the 1960s the Imperial War Museum led the way in the recording of memories of historic episodes, while many museums now record memories of life experiences and received memories (that is, passed on, for example by parents). As she makes clear, a key difference that has emerged between museum recording of oral histories and that carried out by others is the relationship with objects. This began with rural and industrial museums prioritizing 
memories that were about skills or procedures and the use of objects. It has since moved on to the wider issue of the meanings people attribute to objects, the development of new museums and galleries based on life stories, and the creation of associated new collections. ${ }^{37}$ An early UK example can be seen in The People's Story in Edinburgh developed in the 1980s. While this certainly reflects a democratization of content, it is still about the construction of a collective memory, of a shared past that people could take pride in. As Helen Clark, the curator of The People's Story wrote: 'Edinburgh people should feel that the museum is for and about them, and for them to have a sense of pride in their own past and history'. ${ }^{38}$ Starting from the representation by museums of a white working class, the development of a multi-perspectival approach has become increasingly important as western society has become more multicultural. Again, new collections have been developed, mostly through outreach programmes in which museums have worked in partnership with minority communities within their localities and which have combined oral histories with collecting. ${ }^{39}$ But museums have also developed proactive policies on revisiting existing collections to draw out new relevances. ${ }^{40}$ Thus museums have begun to see their role change from the collection and presentation of a single authorised past to that of cultural mediator, incorporating and representing the memories of previously marginalised groups. ${ }^{41}$

This representation of multiple perspectives has also fed back into an ongoing re-definition of collective memory. In the past, a dominant group could define the collective memory for a community or nation, with minority groups welcomed in if they accepted that version or otherwise cast as outsiders. Today, instead, we have recognition that differing points of view can be incorporated within the collective, rather than collective memory speaking with a single authorised voice - in fact individual and group memories become essential parts of the collective, made part of 
the wider community's memory by the very act of being shared. ${ }^{42}$ Representation and inclusion within the collective is also an essential element in the construction of both individual and community identity, for themselves and for others - a sense of belonging over time and space, of their place in the human story. In collecting and transmitting community memory, museums have therefore also become involved in the construction and mediation of community identity.

\section{Museums, memory and history: issues and future directions}

In this article I have come a long way, from stone hand tools as a distant trace memory of human origins to memory museums as critical tools in support of human rights and as cultural mediators in modern multicultural societies. In reality, the paper reflects both the complexity of museums themselves in the variety of their response to the concept of memory and also the independent meanings that visitors make as a result of their engagement with museum content. Museums are only at the beginning of the process of combining community memories and multiple perspectives into their activities but these are likely to be key issues for the foreseeable future. The acquisition of new material will continue to focus on previously marginalised communities and will include both new collecting and the drawing out of new meanings/memories from existing collections, but almost certainly concentrate on alternative forms of evidence, particularly photographs, archive film and oral histories. Transmission will involve increasing use of the internet and other forms of digital media as well as experimentation with new means of display and programming. I place the internet first here, because it is frequently easier, cheaper and faster for museums to develop their virtual provision than to change the bricks and mortar and display media of their exhibitions. 
The opportunities are tremendous. A key starting point is for the museum to look outwards, beyond its walls, housed collections and 'safe' history. A history museum's most important exhibit should be the locality it serves and museums are increasingly seeking to encourage local communities to investigate their own pasts, share their experiences and enthuse museum visitors to go out and actively explore the locality, using local voices (live or audio) to reach below the surface patina. Oral and written testimonies, short films, soundscapes and images contribute to a wider understanding of a locality's complex culture and history, and could include the recording of personal experiences/life stories as part of the museum's role as a repository of community memory. You can see this, for example, in the collaboration between Missouri History Society and the communities of St Louis in exploring the cultural landscapes of the city (www.historyhappenedhere.org). From such initiatives, some history museums, particularly in the USA, are beginning to develop approaches to display that engage users with the lived experiences of others to encourage reflection and understanding. This relates directly to an increasing ambition on a local, national and international level to see museums as centres for civil engagement, with a primary role in reducing tension between community memories and promoting understanding between communities. ${ }^{43}$ This type of exhibition raises many questions. Does it lead to a deep healing process or achieve no more than a temporary catharsis? Is there an achievable balance between the intensely personal nature of individual memory and the wider context that history seeks to provide?

There are many successful, evaluated examples. Partnership with individuals or organizations like Facing History (www.facinghistory.org) with expertise in conflict resolution and in engaging communities and school students with historical issues like racism and anti-semitism, can make a major difference. However, there is no 
guarantee that the approach will work, or that previously marginalised individuals and communities will be willing to consider a view of the past that does not support their sense of conflict with the mainstream and with each other. ${ }^{44}$ In seeking to incorporate the lived experiences of the previously marginalised, there will always be a risk either that museums will reflect perspectives in their content that they feel comfortable with - or, alternatively, give too much space to those groups which have the strongest sense of past neglect or persecution and have pushed hardest to have their stories told. Each of these approaches effectively invites in some previously marginalised groups to become part of the 'authorised version' of the past while others will remain silent and ignored.

Any relevant form of community engagement in collection building and display or website development also immediately raises the vexed issue of sharing authority for content. Sharing authority means confronting a primary fear of all professionals, not just museum curators, of their expertise not being recognized and of losing control. But, if a museum is committed to recording and sharing the memories of the communities it serves, curators must willingly commit to partnerships of equals. In Leicester, for example, the museum service worked with groups from the local Asian community to create an exhibition and website on their experiences of moving to England. This was part of a national project (www.movinghere.org.uk) led by the National Archives which, to date, has involved over 35 archives, museums and libraries and 45 community groups. However, sharing authority must always be underpinned by the understanding that with such authority comes trust - the trust of museum users in the content provided. In the case of 'Moving Here', the National Archives retained overall powers to select and edit content. Whilst it has not yet happened in this project, one can see the potential for conflict between community memory and the more objective picture of the past that history is expected to 
provide. This can particularly be the case where community memory and historians disagree - what a marginalised community feels happened to it in the past, and is embedded in its collective memory, can be far more important to it in the present than what really did happen. Who, in these circumstances, retains the authority to edit content and with what purpose?

Editing can also be an essential element in response to visitor contributions within galleries, triggered by display content. In the 'Conflicts' exhibition at the Ulster Museum (2007-2008), the 'Troubles' of the last 40 years were placed within the context of conflict in Ireland since prehistoric times. Individual and community users of the exhibition from across the political divide brought their ideas, feelings and personal experiences with them, while the museum acted as a 'mediator of many voices' and provided a context that enabled people to express and perhaps reassess their views.

Underpinning all of this is a need for museum personnel to develop new skills: in working with communities; in mediating between community memories; and in developing new approaches to display and online provision that are based on shared contributions, and for museums to be accepted by communities as neutral spaces. This will take much time and involve reaching out to marginalised groups who have in the past seen museums as 'not for us'.

Finally, in bringing together museums, memory and history, one cannot lose sight of the core underlying issue, the nature of history itself. Whilst academic historians continue to seek to present accounts of the past that are plausible and testable by other historians, history museums are developing a different sort of history, one embedded in the lived experiences of the communities they serve and driven by community memories. At their best, this is exhilarating. However the risk remains that, in seeking to be inclusive of all the communities they serve, such 
museums are at risk of using the past purely to meet the needs of the present. In this changing picture of what 'history' means to museums and the communities they serve, the chasm between curators of history museums and historians is a wide one. There is little collaboration between the two and this will continue to be the case unless research bodies can be convinced to grant equal value to the team effort that is involved in creating a history museum that is accorded to individual research. Yet, museums badly need that academic input while academic historians, and the subject itself, could benefit greatly from involvement in museum projects.

\footnotetext{
${ }^{1}$ Eric Gable and Richard Handler 'Public History, Private Memory', in Amy K. Levin (ed.) Local museums and the construction of history in America's changing communities (Walnut Creek, CA, 2007) p60
}

${ }^{2}$ Michelle Henning Museums, Media and Cultural Theory (Maidenhead, Open University Press, 2006) p137

${ }^{3}$ Sheila Watson 'Myth, Memory and the Senses in the Churchill Museum', in Sandra H. Dudley (ed.) Museum Materialities: objects, engagements, interpretation (Oxford, Routledge, 2010) p 205 ${ }^{4}$ Tony Bennett Pasts Beyond Memory: Evolution, Museums, Colonialism (London, Routledge, 2004) p2

${ }^{5}$ Ibid., p4. For a detailed discussion of this, see Laura Otis (1994) Organic memory: History and the Body in the Late Nineteenth and Early Twentieth Centuries, Lincoln, NB: University of Nebraska Press

${ }^{6}$ Ibid., pp 59-60

${ }^{7}$ Stephanie Moser Wondrous Curiosities: Ancient Egypt at the British Museum (Chicago, University of Chicago Press, 2006) p5

${ }^{8}$ Jules David Prown 'The Truth of Material Culture: History or Fiction?', in Steven Lubar and W. David Kingery (eds) History from Things: Essays on Material Culture (Washington, Smithsonian Institution, 1993) $\mathrm{pp} 2-3$

${ }^{9}$ Jan Assman Religion and Cultural Memory (Stanford CA, Stanford University Press, 2006) p24 
${ }^{10}$ Susan A. Crane 'Introduction', in Susan A. Crane (ed.) Museums and Memory (Stanford, CA, Stanford University Press, 2000) p3

${ }^{11}$ Ibid, p2

${ }^{12}$ Marius Kwint 'Introduction: The Physical Past', in Marius Kwint, Christopher Breward and Jeremy Aynsley (eds) Material Memories (London, Berg, 1999) p5

${ }^{13}$ Gaynor Kavanagh Dream Spaces: Memory and the Museum (Leicester, Leicester University Press, 2000) p3

${ }^{14}$ Alberto Gallace and Charles Spence Ch11 'A Memory for Touch: The Cognitive Psychology of Tactile Memory', in Helen J. Chatterjee (ed.) Touch in Museums: policy and practice in object handling (Oxford, Berg, 2008) pp163-186

${ }^{15}$ Bernie Arigho (2008) Ch14 'Getting a Handle on the Past: The Use of Objects in Reminiscence Work', in Helen J. Chatterjee (ed.) Touch in Museums: policy and practice in object handling (Oxford, Berg, 2008) p205

${ }^{16}$ Prown, 'The Truth of Material Culture', p1

${ }^{17}$ Geoffrey Cubitt History and Memory (Manchester, Manchester University Press, 2007) p179

${ }^{18}$ Meredith Blake 'Navigating our Pacific Heritage: museums preserving traditions, mediating development and building local, regional and international relationships', Intercom Conference; 'New Roles and Missions for Museums', Taipei, Taiwan, 2-4 November 2006, accessed on $20^{\text {th }}$ November 2009 at www.intercom.museum/documents/4-4Blake.pdf

${ }^{19}$ Assman, Religion and Cultural Memory, pp82-83

${ }^{20}$ John E. Crowley The Invention of Comfort: Sensibilities and Design in Early Modern Britain and Early America (Baltimore, The Johns Hopkins University Press, 2000)

${ }^{21}$ Kay F. Edge and Frank H. Weiner 'Collective memory and the Museum', in lan Russell (ed.) Images, Representations and Heritage: moving beyond modern approaches to archaeology (New York, Springer, 2006) p227

${ }^{22}$ Theodor W. Adorno (trans Samuel Weber) Prisms (Cambridge: MIT Press, 1982)

${ }^{23}$ Pierre Nora (1989) 'Between memory and history: les lieux de memoire', Representations 26 (1989): 7- 25

${ }^{24}$ Ibid., p7

${ }^{25}$ Tony Bennett 'Stored virtue: memory, the body and the evolutionary museum', in Susannah Radstone and Katharine Hodgkin (eds) Regimes of memory (London, Routledge, 2003) pp40-54 
${ }^{26}$ For an introduction to Ecomuseums, see Peter Davis 'New Museologies and the Ecomuseum', in Brian Graham and Peter Howard (eds) The Ashgate Research Companion to Heritage and Identity (Aldershot, Ashgate, 2008) pp397-414

${ }^{27}$ Henning, Museums, Media and Cultural Theory, p119

${ }^{28}$ Taken from the website of the International Coalition of Sites of Conscience, accessed on 21/04/2009 at www.sitesofconscience.org

${ }^{29}$ Liz Ševčenko (author), Liam Mahony (ed.) (2004) The Power of Place: how historic sites can engage citizens in human rights issues (Minneapolis, Centre for Victims of Torture, 2004) accessed on 16/04/2009 at www.sitesofconscience.org/wp-content/documents/publications/power-of-placeen.pdf, p6

${ }^{30}$ Susan A. Crane 'Writing the Individual Back into Collective Memory, AHR Forum: 'History and Memory', American Historical Review 103 (5), December 1997: 1372-1385, p1373

${ }^{31}$ Patricia Davison (2005) 'Museums and the re-shaping of memory', in Gerard Corsane (ed.) Heritage, Museums and Galleries: an introductory reader (London, Routledge, 2005) pp184-194, p186

${ }^{32}$ David W. Blight 'The Memory Boom: Why and Why Now?', in Pascal Boyer and James V. Wertsch (eds) Memory in Mind and Culture (Cambridge, Cambridge University Press, 2009) pp238-251

${ }^{33}$ Cheryl Mezaros (2008) Un/Familiar', in Journal of Museum Education 33(3) Fall 2008: 239-246, p243

${ }^{34}$ Davison, 'Museums and the re-shaping of memory', p186

${ }^{35}$ Gaynor Kavanagh Dream Spaces: Memory and the Museum (London, Leicester University Press, 2000) p99. See also Gaynor Kavanagh History Curatorship (Leicester, Leicester University Press, 1990) and (1993) 'The future of social history collecting' Social History Curators Group 20 (2004): 6165. See also Kevin Moore Museums and Popular Culture (Leicester, Leicester University Press, 1997)

${ }^{36}$ David Fleming (1999) 'Making City Histories', in Gaynor Kavanagh (ed.) Making Histories in Museums (Leicester, Leicester University Press, 1999), pp131-142, p134. See also Stuart Davies (1985) 'Collecting and recalling the twentieth century', Museums Journal 85:1 (1985): 27-30

${ }^{37}$ Gaynor Kavanagh Dream Spaces: Memory and the Museum, chapters 8 and 9 
${ }^{38}$ Helen Clark (1988) 'Changing relationships between museums and the community', in L. Beevers,

S. Moffat and H. Clark Memories and Things: Linking Museums and Libraries with Older People, (South-East Scotland District, Edinburgh, WEA, 1988) pp17-21, p19

${ }^{39}$ For a large scale project, see www.movinghere.org.uk - a major initiative led by the National Archives and involving over 30 archives and museums and a multitude of community groups. It explores and records the life experiences of people who have come to England over the last 200 years and has involved collecting oral histories, images and objects. Over 200,000 items are available through the online catalogue.

${ }^{40}$ See, for example, Helen Denniston Associates Holding up the Mirror: Addressing Cultural Diversity in London's Museums (London: London Museums Agency, 2003) and Val Bott, Alice Grant and Jon Newman Revisiting Collections: discovering new meanings for a diverse audience (London, London Museums Agency, 2005)

${ }^{41}$ Barbara Misztal Theories of Social Remembering (Maidenhead, Open University Press, 2003) p20

${ }^{42}$ Crane, Writing the Individual back into Collective Memory, p1376

${ }^{43}$ See Graham Black 'Embedding Civil Engagement in Museums', Museum Management and Curatorship, 25: 2 (June 2010): 129-146

${ }^{44}$ Paul Connerton How Societies Remember (Cambridge, Cambridge University Press, 1989) p19 